\title{
Biochemical Evaluation of a Potentially Ubiquitous Element in Snake Bite: Myths and Facts-A Tertiary Rural Hospital Study in India
}

\author{
Harish Rangareddy ${ }^{1 *}$, Shashidhar K N² , Deena C Mendez ${ }^{3}$, Prabhavathi K ${ }^{1}$ \\ ${ }^{1}$ Associate Professor, Department of Biochemistry, Sri Devaraj Urs Medical College, Tamaka, Kolar, Karnataka 563101, India \\ ${ }^{2}$ Professor and HOD, Department of Biochemistry, Sri Devaraj Urs Medical College, Tamaka, Kolar, Karnataka 563101, India \\ ${ }^{3}$ Assistant Professor, Department of Biochemistry, Sri Devaraj Urs Medical College, Tamaka, Kolar, Karnataka 563101, India
}

\begin{abstract}
DOI: $10.36348 /$ sjbr.2020.v05i11.004
| Received: 22.10.2020 | Accepted: 01.11.2020 | Published: 07.11.2020
\end{abstract}

*Corresponding author: Harish Rangareddy

\section{Abstract}

Introduction: Snake bite is a significant cause of mortality and morbidity in tropical and sub-tropical countries. Snake venom is a complex mixture containing peptides, polypeptides, enzymes, glycoproteins and other substances which have pharmacological properties. It mainly affects the vital organ systems such as the cardiovascular, nervous, renal and respiratory systems. Studies have shown that following the bite krait snake, patients suffer from hypokalemia and sink into coma. However, no clear conclusive result has been arrived at in studies conducted in rural Kolar district. Objective: To explore the biochemical changes with respect to renal disturbances in snake bites. Methodology: This is a hospital based observational study since these parameters were studied after the snake bite and at the time of admission; data was collected from our hospital records and includes the measured values of blood urea, serum creatinine, serum sodium and potassium levels, bleeding time and clotting time at the time of admission in 30 snake bite victims. These cases were compared with age and gender matched healthy controls. Results: Blood urea and serum creatinine levels were not elevated in the victims while serum potassium level was decreased $(\mathrm{p}<0.001)$ and serum sodium was increased $(\mathrm{p}<0.05)$. Bleeding time was also increased $(\mathrm{p}<0.001)$ when compared to controls. Conclusion: The hypokalemia observed may be due to increased urinary excretion or intracellular shifting of potassium.

Keywords: Hypokalemia, renal function, snake bite.

Copyright (C) 2020 The Author(s): This is an open-access article distributed under the terms of the Creative Commons Attribution 4.0 International License (CC BY-NC 4.0) which permits unrestricted use, distribution, and reproduction in any medium for non-commercial use provided the original author and source are credited.

\section{INTRODUCTION}

Since ancient times, snakebite envenomation has been known to man and references to snakebite are found even in the oldest medical writings. Snakebite is a significant cause of mortality and morbidity in tropical and sub-tropical countries [1]. As a tropical country, India has a diversity of both venomous and non-venomous snakes. It is a major occupational hazard for farmers and claims a large number of lives. Snakebite-related mortality rate in India is 15000 per annum [2]. However, these statistics are inconclusive, as most snakebites occur in villages and forests and all victims may not reach hospital in time for management. Statistics from epidemiological study of snakebites in western Rajasthan in the years 1981-1985 showed that the majority of victims belong to the group of rural people who are farmers in the productive age, so any loss of life in snakebite may severely affect the economy of the victim's family as well as society [3]. This is also true with respect to rural Kolar district.
Common snakes found in India causing mortality and morbidity are cobra (Naja naja), common krait (Bungarus caeruleus), Russell's viper (Daboia russeli) and saw scaled viper (Echis carinatus) [2]. Snake venom has been considered to be one of the most complicated of all toxins produced by either plants or animals [4, 5]. Snake venom contains a complex mixture of peptides, polypeptides, enzymes and glycoproteins with varied biochemical properties. Around 26 different enzymes have been isolated from snake venom but no single species venom contains all of these enzymes. The important enzymes in snake venom includes proteolytic enzymes, thrombin like enzymes, arginine ester hydrolase, collagenase, hyaluronidase, phospholipase A2, phospholipase B, phospholipase C, lactate dehydrogenase, phosphomonoesterase, phosphodiesterase, acetylcholinesterase, RNase, DNase and 5' nucleotidase [6]. These enzymes can damage the cell membrane and the vital organs including cardiovascular, nervous, renal and respiratory systems $[7,8]$. Generally, snake venom is classified as 
hemotoxic and neurotoxic. Elapid venom contains high concentrations of neurotoxins, and its clinical manifestations are neuromuscular paralysis, ptosis, ophthalmoplegia and bulbar paralysis. Viper venom is hemotoxic and exhibit hemorrhage [2]. Potassium is a ubiquitous cation present intracellularly in all cells. This cation in response to the toxic enzymes in snake venom causing cell membrane rupture and also due to secondary effect of renal failure can be elevated in serum manifesting as hyperkalemia. However, there have been conflicting reports of hypokalemia being seen in cases of snakebite $[9,10]$.

Studies conducted by Kularatne et al., in Sri Lanka have observed deep coma and hypokalemia in patients following krait snake bites [9]. In their study, $48 \%$ of patients were severely envenomed and needed mechanical ventilation while the cardinal symptom was abdominal pain. ECG changes due to hypokalemia include broad flat $\mathrm{T}$ waves, ST depression and QT prolongation and these are most prominent when serum potassium levels are less than $2.7 \mathrm{mEq} / \mathrm{L}$. Hypokalemia also results in hyperpolarization of skeletal muscles and thus impairs the capacity to depolarize and contract; and consequently weakness and paralysis may ensue. It also causes a skeletal myopathy and predisposes to rhabdomyolysis [11]. Hence, following envenomation, the biochemical responses to the venom toxins and etiologies for mortality needs to be evaluated. This study was aimed to assess biochemical changes and other clinical findings in snakebite victims in Kolar, Karnataka, India.

\section{METHODS \\ Study Design and Patients}

This study was carried out in R.L. Jalappa Hospital and Research Center, a rural tertiary care hospital situated in Kolar district of India during June 2011, as review of hospital statistics during the past 5 years revealed that the incidence of snake bite was higher during June-July, probably due to the onset of pre-monsoon every year. Data of thirty patients admitted in the medical ICU suffering from snake bite was collected from patient files available with the medical records section of the hospital, after obtaining the ethical clearance from the institutional ethics committee. Identification of species was based on the history provided by victim or the person who accompanied him to the hospital. The data collected at the time of admission were blood glucose, blood urea, serum creatinine, serum sodium and potassium, bleeding time and clotting time. Thirty age and gendermatched healthy subjects who did not have any acute or chronic illnesses known to alter the analytes of interest were taken as controls.

\section{STATISTICAL ANALYSIS}

Data collected was tabulated and findings are reported descriptively as mean and standard deviation. The normality of distribution of parameters was tested using Shapiro Wilk's test. Independent t- test was used to compare the difference of means between patients and healthy controls. Data were analyzed using SPSS software and $\mathrm{P}$ value of less than 0.05 was considered as statistically significant.

\section{RESULTS}

Most of the cases were brought to the hospital within 4 hours after the incident. Among the victims there was male predominance, the male to female ratio was 2:1 suggesting a special risk of outdoor activity. In our study, the various species of snake bite were cobra $20 \%$, viper $27 \%$ and unknown snake $53 \%$. Most bites were that by unidentified species and occurred in the lower extremities.

Blood urea and serum creatinine levels were not elevated in all snakebite cases. The mean \pm standard deviation values of blood urea (reference range: 20-40 $\mathrm{mg} / \mathrm{dL}$ ) were $24.5 \pm 20.2 \mathrm{mg} / \mathrm{dL}$ in cases and $27.2 \pm$ $10.1 \mathrm{mg} / \mathrm{dL}$ in controls, and values for serum creatinine (reference range: $0.6-1.4 \mathrm{mg} / \mathrm{dL}$ ) were $0.9 \pm 0.6 \mathrm{mg} / \mathrm{dL}$ in cases and $0.8 \pm 0.2 \mathrm{mg} / \mathrm{dL}$ in controls. Serum potassium level (reference range: $3.5-5.0 \mathrm{mEq} / \mathrm{L}$ ) was significantly decreased in cases compared to controls $(3.0 \pm 0.7$ vs. $4.2 \pm 0.4 \mathrm{mEq} / \mathrm{L} ; \mathrm{P}<0.001)$. Although the serum potassium values in cases were lower than the reference range, no clinical complications of hypokalemia were observed. Serum sodium level (reference range: $135-145 \mathrm{mEq} / \mathrm{L}$ ) was significantly higher cases compared to controls $(140.1 \pm 5.5 \mathrm{mEq} / \mathrm{L}$ vs. $137.2 \pm 4.8 \mathrm{mEq} / \mathrm{L} ; \mathrm{P}<0.05)$. 


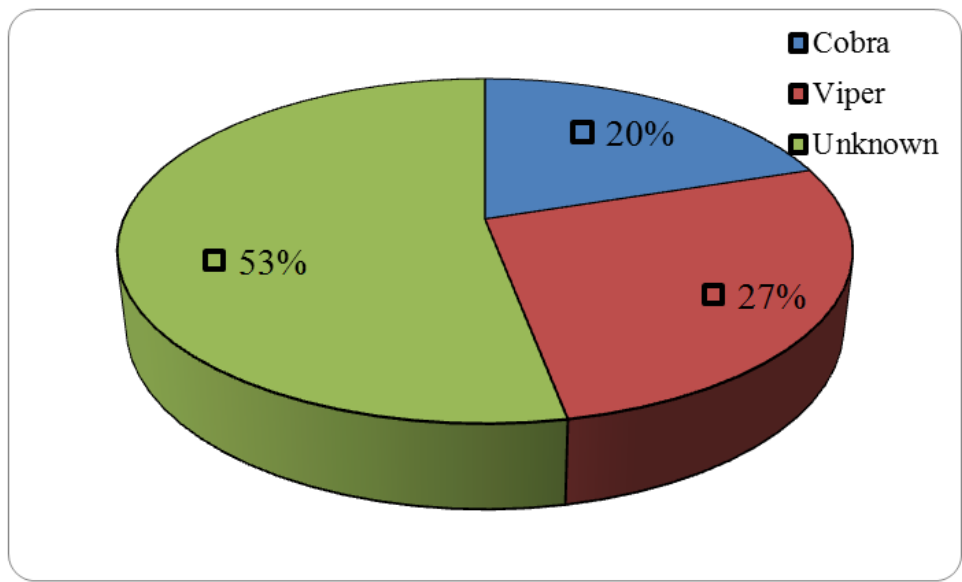

Fig-1: Percentage distribution of various snake bites

Table-1: Comparison between Cases and Controls

\begin{tabular}{|l|l|l|l|l|l|l|}
\hline Parameter & $\begin{array}{l}\text { Reference } \\
\text { range }\end{array}$ & $\begin{array}{l}\text { CONTROLS Mean } \pm \\
\text { SD } \\
\mathbf{n = 3 0}\end{array}$ & $\begin{array}{l}\text { CASES Mean } \pm \\
\text { SD } \\
\mathbf{n = 3 0}\end{array}$ & $\begin{array}{l}\text { 't' } \\
\text { value }\end{array}$ & $\begin{array}{l}\text { df 'p' } \\
\text { value }\end{array}$ \\
\hline BT $(\mathrm{sec})$ & $30-360$ & $129 \pm 30$ & $177.5 \pm 65.6$ & 3.656 & 58 & $<0.001$ \\
\hline CT $(\mathrm{sec})$ & $300-600$ & $276.8 \pm 47.3$ & $320.3 \pm 111.7$ & 1.963 & 58 & 0.054 \\
\hline RBS $(\mathrm{mg} / \mathrm{dl})$ & $75-140$ & $126.4 \pm 79.5$ & $118.3 \pm 55.09$ & -0.462 & 58 & 0.646 \\
\hline Blood urea (mg/dl) & $20-40$ & $27.03 \pm 10.14$ & $24.5 \pm 20.2$ & -0.614 & 58 & 0.542 \\
\hline $\begin{array}{l}\text { Serum Creatinine } \\
\text { (mg/dl) }\end{array}$ & $0.6-1.4$ & $0.83 \pm 0.2$ & $0.89 \pm 0.61$ & 0.527 & 58 & 0.6 \\
\hline Sodium (mEq/L) & $135-145$ & $137.23 \pm 4.8$ & $140 \pm 5.53$ & 2.166 & 58 & 0.034 \\
\hline Potassium (mEq/L) & $3.5-5.0$ & $4.17 \pm 0.44$ & $3.04 \pm 0.65$ & -7.791 & 58 & $<0.001$ \\
\hline
\end{tabular}

\section{DISCUSSION}

Snakebites are not systematically reported in most countries. Moreover, very few countries possess a reliable epidemiological reporting system capable of providing precise data on snakebites [12]. Most of the available data are based on hospital statistics which constitute a very small percentage of snakebite cases because many victims are still being treated mostly by traditional methods rather than in the hospitals.

The peptides and polypeptides in snake venom exert a wide array of toxic properties [13]. The clinical manifestations of snake bite are dependent on two factors, the intrinsic toxicity and amount of venom injected. The cobra venom consists of three types of proteins namely cardiotoxin, neurotoxin, and phospholipase A2 (PLA2). Cobra neurotoxins interact with the post-synaptic acetylcholine receptor while cardiotoxins show no defined cellular targets and have very diverse pharmacological effects, including lethal toxicity, hemolysis, muscle contracture, and activation of tissue phospholipase C. Severe inflammation and necrosis in the affected tissue area may be due to the cardiotoxins and/or PLA2 or their synergistic effect.

The bite of common Krait (Bungarus caeruleus) bite may not be painful and the local manifestations are barely discernible, but systemic symptoms and abdominal pain are the distinctive features of a krait envenomation, along with hypokalemia [10]. Following cobra and krait bite, there will be neuromuscular paralysis of palate, tongue, pharynx and respiratory muscles, coma and death occurs due to respiratory failure or shock. Russell's viper and Saw scaled viper possess hemotoxic venoms. Following viper bite hemorrhagic manifestations and bleeding leads to shock, tachycardia, myocarditis and cardiac failure [15]. One of complications of snake envenomation is acute renal failure. Acute renal failure due to snakebite mostly occurs following rhabdomyolysis and rhabdomyolysis is usually seen following Elapidae envenomation.

There was no gross observable difference in the blood urea and serum creatinine levels between cases and controls; thus the secondary effect of renal failure on serum levels of sodium and potassium are ruled out. In one case of viperine envenomation where the patient had developed acute renal failure (blood urea $=123 \mathrm{mg} / \mathrm{dl}$ and serum creatinine $=4 \mathrm{mg} / \mathrm{dl})$, his serum sodium was $121 \mathrm{mEq} / \mathrm{L}$ and serum potassium was $3.7 \mathrm{mEq} / \mathrm{L}$. Hospital stay for this patient was prolonged but the patient recovered. However, in an experimental study done on male wistar rats using Bothrops moojeni species venom it was observed that there was an increased urinary excretion of sodium and potassium after a venom dose of $0.2 \mathrm{mg} / \mathrm{kg}$ without a decrease in glomerular filtration rate (GFR). This finding may reflect differences in response of nephron constituents to nephrotoxic components of venom and 
existence of a threshold of damage beyond which GFR and tubule sodium and potassium handling are independent of each other [16].

Seventy one percent of patients had altered level of consciousness and sixty six percent manifested with autonomic disturbances. The major biochemical disturbances observed were hypokalemia in $71 \%$ and metabolic acidosis in 50\%. Polyvalent antivenom had no significant benefit in reversing respiratory paralysis or preventing delayed neurological complications [9]. This is the impact of the enzymes present in the snake venom.

Kularatne et al., published a case report where the patient was in coma and later developed disseminated intravascular coagulation and acute respiratory distress within a week. Serial analysis of blood sample each day following admission in this patient consecutively for 5 days showed persistent low serum potassium in spite of potassium supplementation [10]. Hypokalemia is known to affect cardiac, skeletal and intestinal muscle cells and it is also a major risk factor for both ventricular and atrial arrhythmias. This finding was persistent in their study and the patient succumbed to death due to asystolic cardiac arrest on day 13.

The occurrence of complications of biochemical alterations were almost absent due to:

i. The patients were brought to the hospital immediately after the snake bite with a tourniquet in situ

ii. Immediate clinical care was given to the patients

iii. The biochemical parameters were analyzed immediately at the time of admission on an emergency basis.

The values observed in our study were within reference range even though the 'p' value was significant and this may be dye to psychological factors and anxiety. Hence, compared to the studies conducted by Kularatne et al., the outcome of the treatment, prevention of complications and saving the life goes with the saying "earlier treatment, better recovery". Bleeding time and clotting time were significantly increased in cases compared to controls $(\mathrm{P}<0.001$ and $\mathrm{P}=0.054$, respectively). Our study is on par with the studies conducted in Sri Lanka by Kularatne et al., where hypokalemia was observed following krait snake bites [9]. Studies conducted by Kumar KMP et al., have shown that there was no significant increase of serum potassium level in both viper and cobra bite cases [2].

Snake venom especially elapids can damage renal nephrons, as this has been observed in experimental studies done on rats, and thus the urinary loss of potassium may occur causing hypokalemia. The other ways by which hypokalemia can occur are extracellular potassium being lost to the gastrointestinal tract or being shifted intracellularly [10]. However, the contribution of gastrointestinal loss in normal potassium homeostasis is minimal [21]. Since extracellular potassium contributes to maintenance of resting membrane potential, shifting of potassium into intracellular compartment could contribute to neuromuscular weakness seen in snake envenomation [10]. Catecholamines and states of endogenous or pharmacological beta adrenergic excess causes intracellular redistribution of potassium [22]. There exists an irrational fear of snakes despite most species being non-venomous. Hence in cognitive behavioral terms snakebite could trigger negative thoughts as a critical incident leading to emotional distress [23]. Emotional stress leads to release of catecholamines especially adrenaline, which causes stimulation of a $\beta$ adrenoceptor linked to membrane sodium/potassium adenosine triphosphatase causing potassium influx. Hence, it can be postulated that $\beta$ adrenergic response due to emotional stress of impending doom is a potential cause for hypokalemia.

\section{CONCLUSION}

In our study hypokalemia was observed in snake envenomation. In the absence of renal impairment hypokalemia in snake bite could be due to increased urinary excretion or intracellular shifting of potassium. Secondly, it could also be due to emotional stress leading to the release of catecholamines, especially adrenaline, which causes stimulation of $\beta$ adrenergic receptors and intracellular shifting of potassium caused by increased $\mathrm{Na}+\mathrm{K}+$-ATPase activity as an adaptive mechanism. Subsequent to the hospital admission the altered potassium homeostasis may revert to normal in absence of secondary effect of renal failure and lead to hyperkalemia causing complications. Hence, caution should be taken with respect to the choice of intravenous fluids, the dosage of anti-snake venom and also serial monitoring of electrolytes and renal function should be done.

\section{Acknowledgement}

Mr. Ravi Shankar, Statistician, Department of Community Medicine, Sri Devaraj Urs Medical College, Kolar.

\section{REFERENCES}

1. Dutta, T. K., \& Mukta, V. (2006). Snake bite. Journal of Indian Medical Association. 104:25052.

2. Kumar, K. P., \& Basheer, M. P. (2011). Snake bite: Biochemical changes in blood after envenomation by viper and cobra. Journal of Medical \& Allied Sciences, 1(1), 36-41.

3. Nayak, K. C., Sharda, D. P., Kochar, D., \& Varma, V. K. (1988). Epidemiological study of snake bites in western Rajasthan in the years 1981-1985. Ind Med Gaz. 122:121-126. 
4. Warrell, D. A. (1999). WHO/SEARO Guidelines for the clinical management of snake bites in the Southeast Asian region. Southeast Asian J Trop Med Public Health. 30:1-85.

5. Bomb, B. S., Roy, S., Kumawat, D. C., \& Bharjatya, M. (1996). Do we need anti snake venom (ASV) for management of elapid ophitoxaemia. The Journal of the Association of Physicians of India, 44(1), 31-33.

6. Pahari, S., Mackessy, S. P., \& Kini, R. M. (2007). The venom gland transcriptome of the Desert Massasauga Rattlesnake (Sistrurus catenatus edwardsii): towards an understanding of venom composition among advanced snakes (Superfamily Colubroidea). BMC molecular biology, 8(1), 115.

7. Nayak, K. C., Jain, A. K., Sharda, D. P., \& Mishra, S. N. (1990). Profile of cardiac complications of snake bite. Indian heart journal, 42(3), 185-188.

8. Sun, J. J., \& Walker, M. J. A. (1986). Actions of cardiotoxins from the southern Chinese cobra (Naja naja atra) on rat cardiac tissue. Toxicon, 24(3), 233245.

9. Kularatne, S. A. M. (2002). Common krait (Bungarus caeruleus) bite in Anuradhapura, Sri Lanka: a prospective clinical study, 199698. Postgraduate medical journal, 78(919), 276280.

10. Gawarammana, I. B., Kularatne, S. A. M., Kularatne, K., Waduge, R., Weerasinghe, V. S., Bowatta, S., \& Senanayake, N. (2010). Deep coma and hypokalaemia of unknown aetiology following Bungarus caeruleus bites: Exploration of pathophysiological mechanisms with two case studies. Journal of Venom Research, 1, 71-75.

11. Harrison. (2012). In: Cardinal manifestations and presentations. Eds. Longo, Fauci, Kasper, Hauser, Jameson, Loscalzo. Harrison's Principles of Internal medicine $18^{\text {th }}$ ed. USA: McGraw Hill Companies, Inc. 353.

12. Chippaux, J. P. (1998). Snake-bites: appraisal of the global situation. Bulletin of the World Health organization, 76(5), 515-524.

13. Bawaskar, H. S. (2004). Snake venoms and antivenoms: critical supply issues. JournalAssociation of Physicians Of India, 52, 11-13.
14. Koh, D. C. I., Armugam, A., \& Jeyaseelan, K. (2006). Snake venom components and their applications in biomedicine. Cellular and Molecular Life Sciences CMLS, 63(24), 3030-3041.

15. Kumar, V., Maheshwari, R., \& Verma, H. K. (2006). Toxicity and symptomatic identification of species involved in snakebites in the Indian subcontinent. Journal of Venomous Animals and Toxins including Tropical Diseases, 12(1), 3-18.

16. Boer-Lima, P. A., Gontijo, J. A., \& da CruzHöfling, M. A. (1999). Histologic and functional renal alterations caused by Bothrops moojeni snake venom in rats. The American journal of tropical medicine and hygiene, 61(5), 698-706.

17. SKou, J. C. (1965). Enzymatic basis for active transport of $\mathrm{Na}+$ and $\mathrm{K}+$ across cell membrane. Physiological reviews, 45(3), 596-618.

18. Schmidt, U., \& Dubach, U. C. (1969). Activity of $(\mathrm{Na}+\mathrm{K}+)$-stimulated adenosintriphosphatase in the rat nephron. Pflügers Archiv, 306(3), 219-226.

19. Nurko, S., Sogabe, K., Davis, J. A., Roeser, N. F., Defrain, M., Chien, A., ... \& Weinberg, J. M. (1996). Contribution of actin cytoskeletal alterations to ATP depletion and calcium-induced proximal tubule cell injury. American Journal of Physiology-Renal Physiology, 270(1), F39-F52.

20. Boer-Lima, P. A., Gontijo, J. A. R., \& CruzHöfling, M. A. (2002). Bothrops moojeni snake venom-induced renal glomeruli changes in rat. The American journal of tropical medicine and hygiene, 67(2), 217-222.

21. Giebisch, G., \& Wang, W. (1996). Potassium transport: from clearance to channels and pumps. Kidney international, 49(6), 1624-1631.

22. Tietz, N. W. (2006). In: Physiology and disorders of water, electrolytes and acid base metabolism eds. Burtis, C. A., Ashwood, E. R., \& Burns, D. E. Tietz textbook of Clinical chemistry and Molecular Diagnostics $4^{\text {th }}$ ed. New Delhi, Elsevier publishers, Rakmo press; 1755.

23. Fita, D. S., Neto, E. C. M., \& Schiavetti, A. (2010). 'Offensive'snakes: cultural beliefs and practices related to snakebites in a Brazilian rural settlement. Journal of Ethnobiology and Ethnomedicine, 6(1), 13. 